\title{
Reduced nuclear translocation of serum response factor is associated with skeletal muscle atrophy in a cigarette smoke-induced mouse model of COPD [Corrigendum]
}

Ma R, Gong XF, Jiang H, et al. Reduced nuclear translocation of serum response factor is associated with skeletal muscle atrophy in a cigarette smoke-induced mouse model of COPD. International Journal of COPD. 2017;12:581-587.
On page 583, left column, last paragraph, the primer for the $I g f 1$ gene forward: $5^{\prime}$-tgctgtccctctatgcttcc-3', reverse: $5^{\prime}$-gaaggaatagccacgctcag-3' should be forward: $5^{\prime}$-tggatgct cttcagttcgtg-3', reverse: $5^{\prime}$-cacaatgcctgtctgaggtg- $3^{\prime}$.

\section{Publish your work in this journal}

The International Journal of COPD is an international, peer-reviewed journal of therapeutics and pharmacology focusing on concise rapid reporting of clinical studies and reviews in COPD. Special focus is given to the pathophysiological processes underlying the disease, intervention programs, patient focused education, and self management protocols.

\section{Dovepress}

This journal is indexed on PubMed Central, MedLine and CAS. The manuscript management system is completely online and includes a very quick and fair peer-review system, which is all easy to use. Visit http://www.dovepress.com/testimonials.php to read real quotes from published authors.

Submit your manuscript here: http://www.dovepress.com/international-journal-of-chronic-obstructive-pulmonary-disease-journal 